COPYRIGHT $\uparrow 1976$ by Physical Biological Sciences Ltd. All Rights Reserved.

\title{
Errata: Electric Field Distribution in Biological Systems
}

\author{
Y. Palti and S. Palti \\ Department of Physiology and Biophysics \\ Technion Medical School \\ Haifa, Israel
}

The publisher regrets that the following figures were left out from the article when it appeared in J. Biol. Phys. 2(1974) 103.

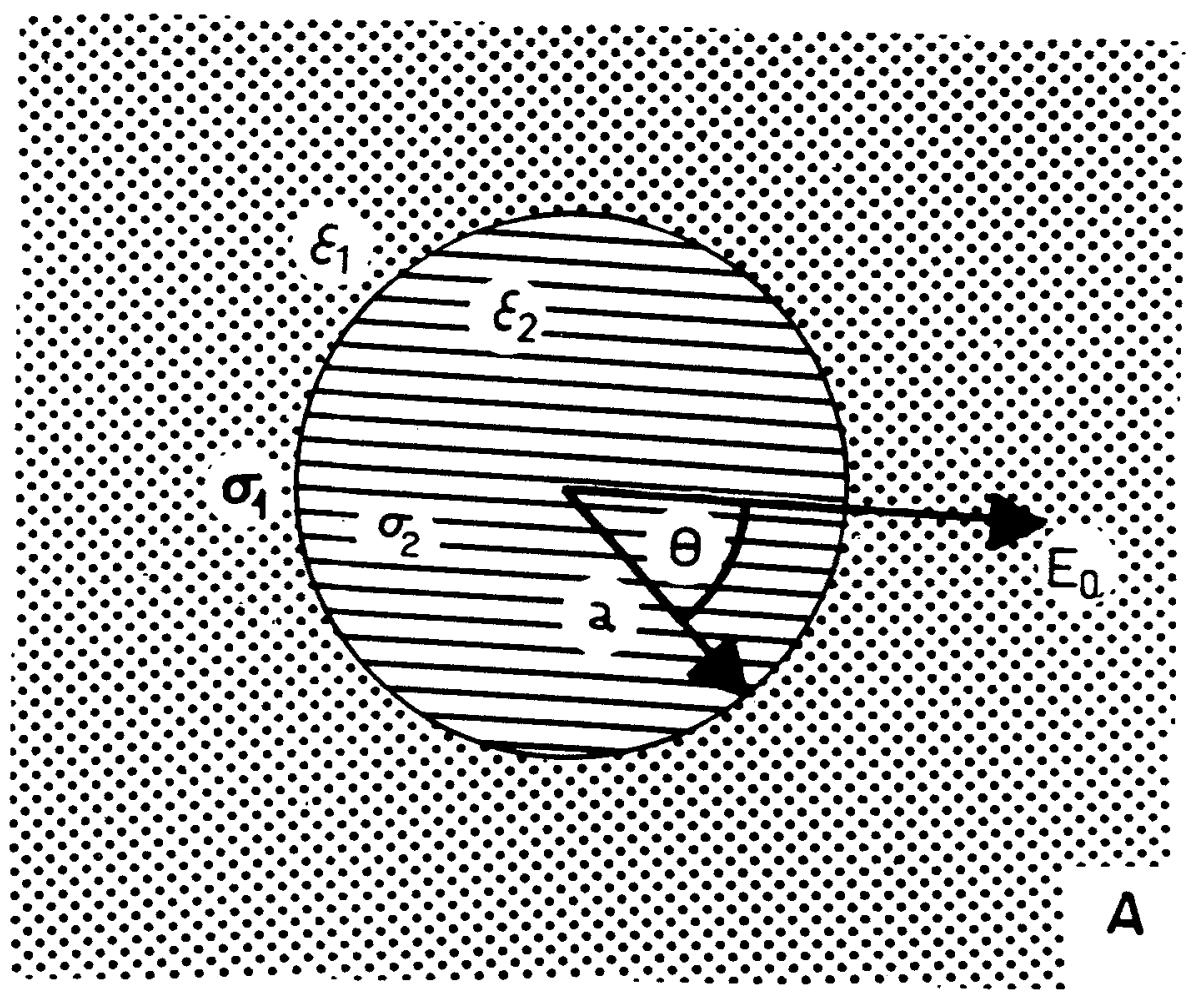




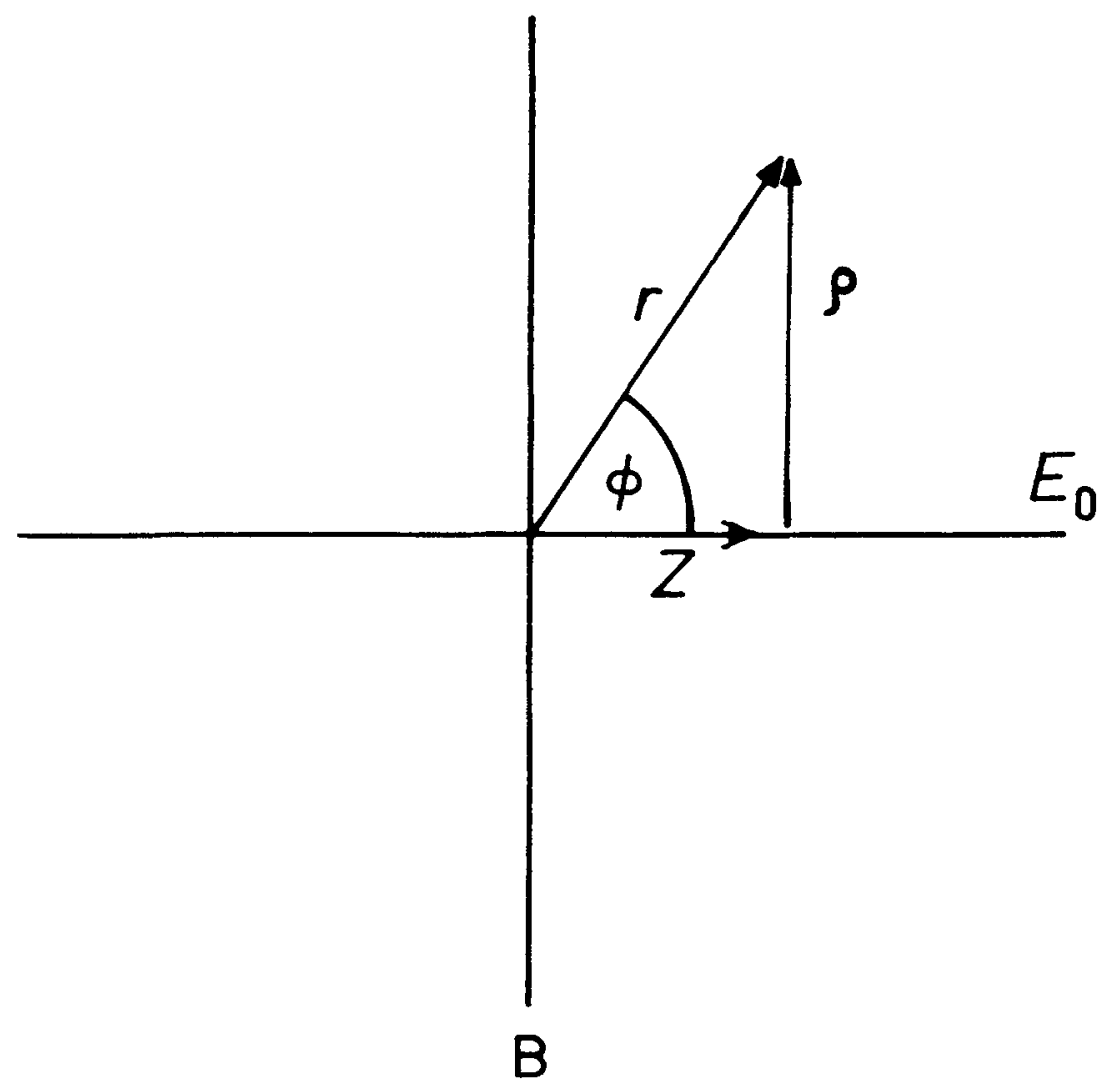

Fig. 1. A) Spherical cell suspended in a homogeneous medium. $\epsilon_{1}$ and $\epsilon_{2}$ are the dielectric constants of the medium and the cell respectively. $\sigma_{1}$ and $\sigma_{2}$ are the conductances of the medium and the cell respectively. $E_{0}$ is the direction of the undistorted field and " $a$ " the cell radius. B) The cylindrical coordinate system used in the solution of the electric field distribution around the spherical cell.

\section{Continued on follou'ing page-}




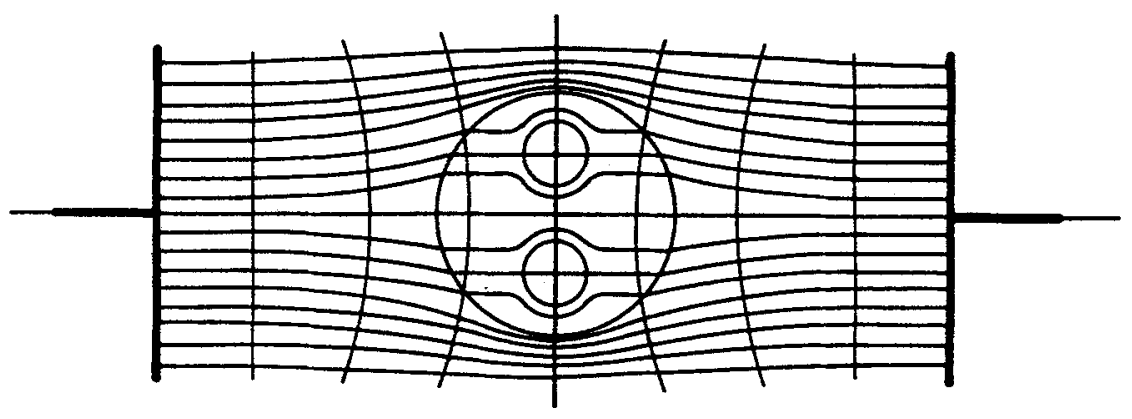

Low Frequencies: below $10^{4}$ c.p.s.

Fig. 2. Schematic presentation of the predicted field distribution in and around a tissue mass suspended in a physiological medium. Note that the field or current density around the whole tissue mass is unaffected by the field frequency, while the density around and inside the individual cells is markedly frequency dependent. L-Low frequencies, H-High frequencies. Further details in text.

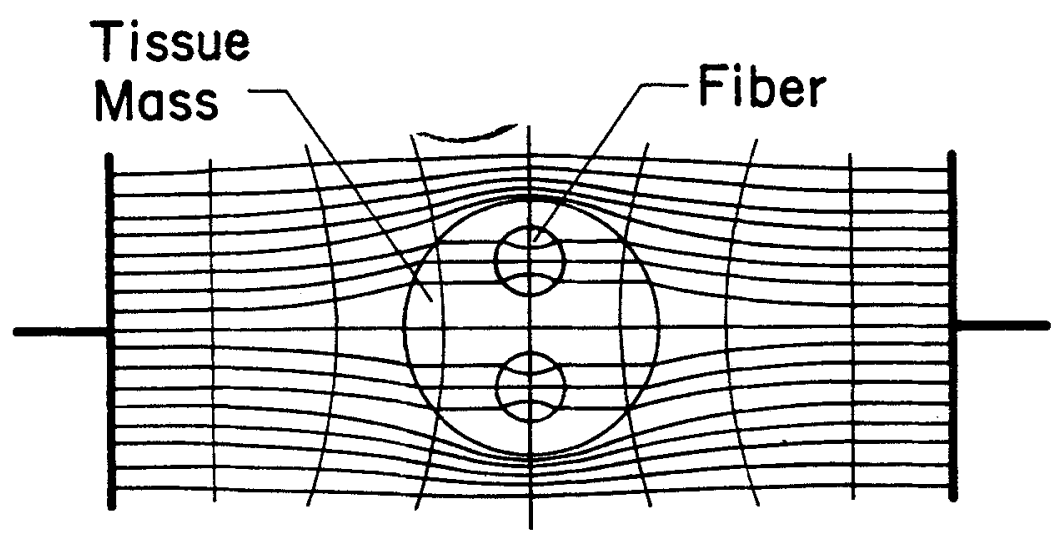

$$
\text { High Frequencies: } 10^{5}-10^{6} \text { c.p.s. }
$$

